Мельниченко О.В., асист., Київський національний торговельно-економічний університет м. Київ, Україна https://scholar.google.com.ua/citations?user=Rw5hvHAAAAAJ\&hl=k

\title{
ПЕРЕДУМОВИ ФОРМУВАННЯ КОРПОРАТИВНОЇ СОЦАЛЬНОЇ ВІДПОВІДАЛЬНОСТІ В ТУРИЗМІ
}

Розвиток туризму як соціально-економічного явища вимагає від сучасного туристичного підприємства участі у соціальних процесах, що виражається у застосуванні підприємством принципів, стандартів та концепцій соціально відповідального бізнесу.

Напрями розвитку туризму тісно пов'язані з трендами подорожей, що змінюються 3 часом. На формування і розвиток туристичного ринку безпосередньо впливають елементи туристичного попиту, що складається 3 різноманітних потреб споживачів. Ці потреби реалізуються суб'єктами туристичного ринку, які повинні підготувати і реалізувати продукт, який буде конкурентний на ринку. Такий продукт включає, як правило, пакет послуг, пов'язаних між собою у часі та просторі.

Сучасні реалії туристичного ринку показали, що українські туристи стикаються 3 тим, що туристичні послуги не відповідають заявленим, а суб'єкти туристичної діяльності (туроператори, турагенти) намагаються уникнути відповідальності або перекласти іiї на третіх осіб.

Це зумовлює необхідність формування та використання нових стратегій та дій у рамках соціальної відповідальності, що спочатку була започаткована у сфері виробництва, а тепер набуває актуальності у сфері туристичного бізнесу.

Слід констатувати, що після кризових 2014-2015 років та протягом останнього часу в Україні спостерігається тенденція піднесення туристичної сфери. Як відомо, стан ринку туристичних послуг залежить від стану економіки і визначається соціальноекономічними та політичними процесами, що відбуваються в країні. Хоча чинники, що не сприяють розвитку, ще залишилися, туристичний ринок виходить зі стану застою. 
За даними державної служби статистики України у 2011 році налічувалось 877 туроператорів і 3512 турагентів [1]. У 2017 році кількість суб'єктів туристичної діяльності значно менша, зокрема, 498 туроператорів і 2802 турагентів. Порівняльну динаміку суб'єктів туристичної діяльності наведено на рис. 1.

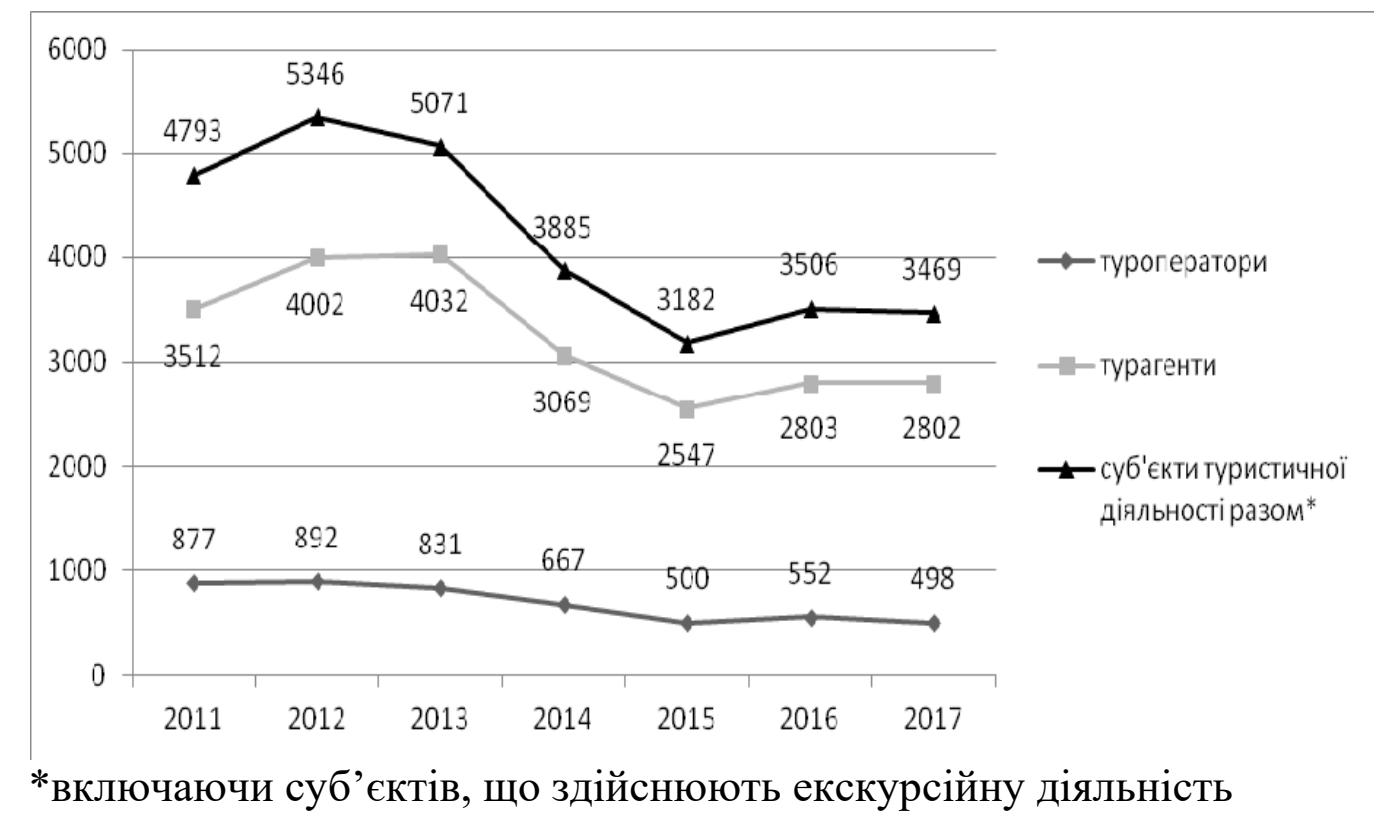

Рис. 1. Динаміка суб'єктів туристичної діяльності за 2011-2017 роки. Створено автором за [1]

Якість послуг українських туроператорів підвищиться, якщо вони будуть впроваджувати у свій менеджмент стратегію корпоративної соціальної відповідальності. Корпоративна соціальна відповідальність (КСВ) передбачає діяльність, яка виходить за межі офіційної юрисдикції, і включає інвестування в людські ресурси, в охорону середовища, а також у відносини із зацікавленими особами (стейкхолдерами), які мають безпосередній вплив на ефективність господарської діяльності організації. (Зацікавлені особи стейкхолдери - це групи людей або індивіди, які можуть впливати на реалізацію цілей організації. До основних стейкхолдерів відносяться: акціонери, працівники організації, клієнти, місцева громада, а також навколишнє середовище [2].

В Україні протягом останніх років стратегії КСВ також починають впроваджуватися в діяльність фірм, менеджерських кадрів, інвесторів, також органів державного управління. Ефекти, що досягаються, популяризація цієї теми через медіа зумовлюють те, що соціальна відповідальність бізнесу стає водночас ефективною рекламою організації чи підприємства. Застосування практики соціальної 
відповідальності можливе не тільки у великих підприємствах, а й у малому та середньому бізнесі, що впливає на збільшення кола прихильників цієї стратегії.

Згідно зі стандартом 26000 (International Organization for Standardization, 2009) соціальна відповідальність бізнесу полягає у врахуванні інтересів суспільства під час прийняття бізнес-рішень, а також взятті на себе відповідальності за вплив усіх аспектів власної діяльності на споживачів, працівників, стейкохолдерів, громаду та навколишнє середовище. В результаті підприємство чи організація не тільки отримає урівноважений розвиток, а соціальна відповідальність буде вбудована в їх структуру управління.

\section{Список бібліографічних посилань}

1. Туристична діяльність в Україні у 2017 році. Статистичний збірник. Державна служба статистики України / Відповідальний за випуск О.О. Кармазіна. - Київ, 2018 [Електронний ресурс] - Режим доступу : http://www.ukrstat.gov.ua/druk/publicat/kat_u/2018/zb/05/ zb_td_2017.pdf

2. Freeman E., Strategic Management : A Stakeholder Approach, Cambridge University Press, New York, 2010. 